\title{
Metasediments in the Alahina Sector and Associated Mineralization (North-Eastern Guinea)
}

\section{Koffi Germain Tchokpon ${ }^{1}$, Christophe Kaki², Glodji Luc Adissin², Soulémana Yessoufou², Mory Kourouma ${ }^{3}$}

${ }^{1}$ Graduate School of Life and Earth Sciences, Faculty of Sciences and Technology (FAST), University of Abomey-Calavi (UAC), Abomey-Calavi, Benin

${ }^{2}$ Department of Earth Sciences, Faculty of Sciences and Technology (FAST), University of Abomey-Calavi (UAC), Abomey-Calavi, Benin ${ }^{3}$ HSSE Department, Higher Institute of Mines and Geology of Boke (ISMG), Boke, Guinea

Email: *germakoff@yahoo.fr

How to cite this paper: Tchokpon, K.G., Kaki, C., Adissin, G.L., Yessoufou, S., Kourouma, M. (2019) Metasediments in the Alahina Sector and Associated Mineralization (North-Eastern Guinea). Open Journal of Geology, 9, 897-918.

https://doi.org/10.4236/ojg.2019.912097

Received: September 26, 2019

Accepted: November 16, 2019

Published: November 19, 2019

Copyright $\odot 2019$ by author(s) and Scientific Research Publishing Inc. This work is licensed under the Creative Commons Attribution International License (CC BY 4.0).

http://creativecommons.org/licenses/by/4.0/

\begin{abstract}
The Alahina sector is located in the North-East of Guinea, precisely in the Siguiri volcano-sedimentary basin. It consists mainly of meta-sediments traversed by Paleoproterozoic pyroclastite, granite, monzogranite and granodiorite veins as well as Mesozoic dolerite and gabbros veins. This article presents new data, on the one hand, on the geochemical petrographic features and the origin of the metasediments of this zone, and on the other hand, on the genetic model of the gold mineralization that they contain. Field observations, as well as petrographic and geochemical studies reveal that the meta-sediments consist of sericite and chlorite schists. They belong to the groups of shales and grauwackes. Their protholites are moderately altered $(60<$ CIA $<80$ ) andesitic, basaltic and granodioritic rocks emplaced in a geotectonic oceanic island arc and/or active continental margin. Their chondrite normalized REE patterns show a moderate LREE enrichment $\left(\mathrm{La}_{\mathrm{N}} / \mathrm{Yb}_{\mathrm{N}}=6.31\right.$ 13.24) and a flat heavy rare earth patterns (HREE). This spectrum is almost identical to those of the "Post-Archean average Australian Shale" and Early Proterozoic Greywackes. Two types of polyphase gold mineralization occur in the Alahina sector: disseminated and veined. They consist of particular of grains and nanoparticles pyrite associated with gold, magnetite, hematite, ilmenite. The hydrothermal alteration accompanying this mineralization consists of silica, microcline, chlorite-epidote-sericite-carbonates.
\end{abstract}

\section{Keywords}

Metasediment, Schist, Sericite, Chlorite, Vein, Quartz, Gold, Alahina, Siguiri Basin 


\section{Introduction}

The Alahina sector is located in northeastern Guinea, in the Siguiri volcano-sedimentary basin, also belonging to the Paleoproterozoic domain of the Man Ridge (Figure 1(a)). Sediments in the Siguiri Basin (Figure 1(b)) rest on an Archean metamorphic basement and include pelititic formations to which the schistose, argilitic to sandstone-feldspathic rocks of the Alahina sector are attached (Figure 2). The maximum age of these rocks, calculated on zircons (U-Pb), is $2124 \pm 7 \mathrm{Ma}$ [1] [2]. These meta-sediments coexist in the Alahina sector with felsic, plutonic and volcanic magmatic units consisting of granodiorites, monzogranites and pyroclastites whose age dates back to $2092 \pm 5 \mathrm{Ma}$ (U-Pb on zircons, [2]-[6]). The similar geological contexts, marked by magmatic, tectonic and metamorphic activity at the green shale gradient, have resulted in West Africa, the establishment of a large gold stock in the meta-sediments [1] [7]-[14]. For this reason, we have carried out the present study which aims to characterize the meta-sediments and mineralization of the Alahina sector from petrographic and geochemical data based on major and

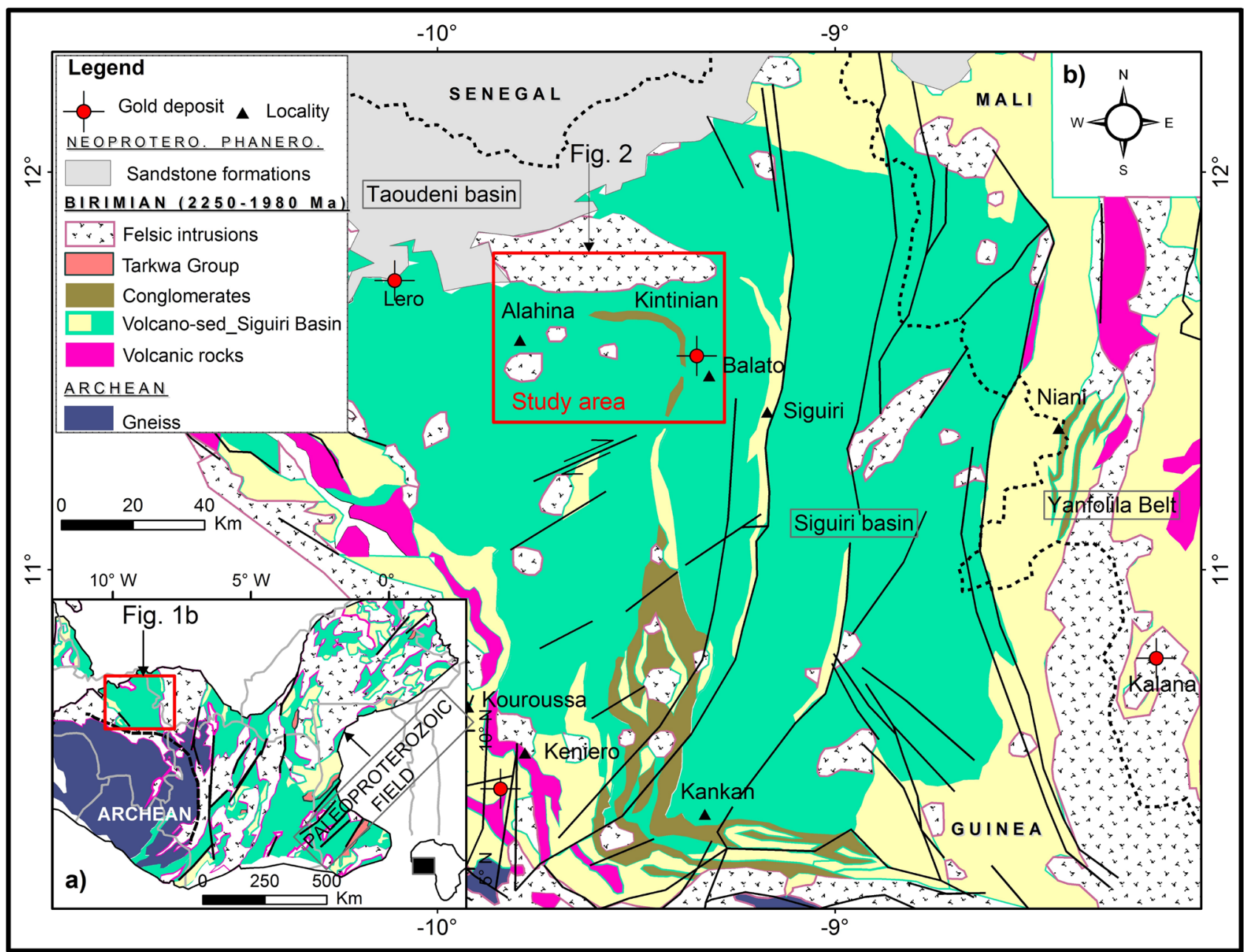

Figure 1. Geological map of the Siguiri volcano-sedimentary basin with location of the study area: (a) simplified geological map of the Man's Ridge and (b) geological map of the Siguiri volcano-sedimentary basin ([15] [16] and modified). 
trace elements. The characteristics highlighted are the nature, provenance and geotectonic environment of meta-sediments and hydrothermal quartz veins they contain.

\section{Geological Setting}

Our study area is located on the Man Ridge (Figure 1(a)). This ridge is composed of two distinct domains: the Archean domain, or Kenema-Man, gneissic, between 2750 and $3540 \mathrm{Ma}$ [9] [17] and the Paleoproterozoic domain, or Baoule-Mossi area, province of volcano-sediments and felsic intrusive rocks of age between 2040 and $2250 \mathrm{Ma}$ [4] [5] [6]. In the Siguiri basin (Figure 1(b)) and north of our study area (Figure 2), the Baoule-Mossi domain is covered with Neoproterozoic sediments belonging to the Taoudeni basin [18] [19].

The collision between the Archean and Paleoproterozoic lands of the Man Ridge during eburnean orogeny (between 1980 and $2210 \mathrm{Ma}$ ) resulted in greenschist-facies metamorphism, magmatic events, and episodes of gold-bearing mineralization [1] [4] [6] [7] [9]-[14]. The gold deposits within the meta-sediments display a wide range of mineralization styles ranging from: intrusion-related gold (e.g. Morila deposit, Mali) [20], orogenic gold (e.g. Obuasi deposit, Ghana, Sadiola

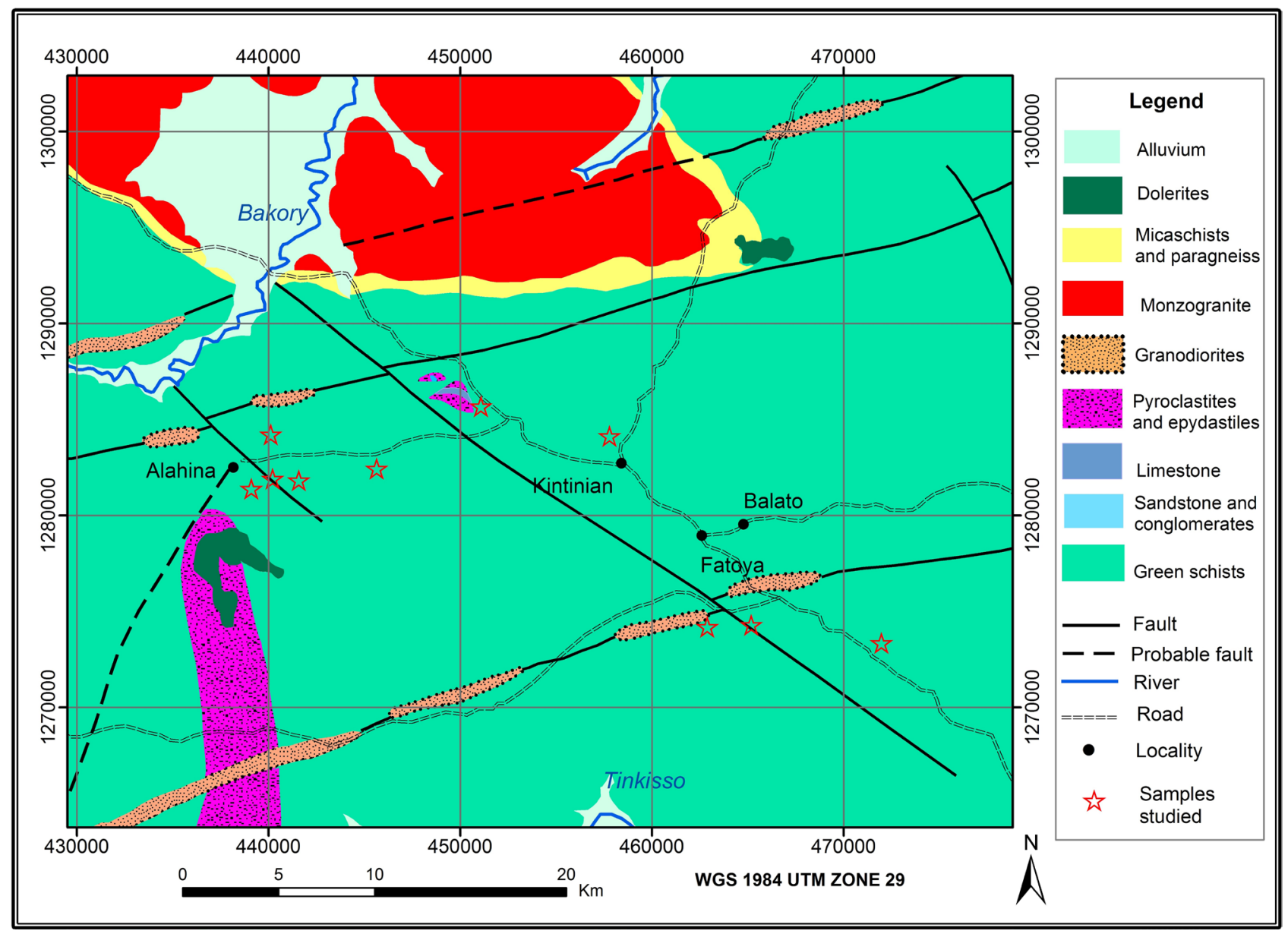

Figure 2. Geological map of the Alahina sector ([21], modified). 
and Loulo, Mali) [1], atypical orogenic gold (e.g. Massawa deposit in Senegal) [22], residuum gold (Yatela deposit in Mali) [23], placer type deposits (e.g. Tarkwa deposit in Ghana, Pigois et al., 2003), 4D orogenic gold (e.g. Siguiri gold deposit, Guinea) [3].

From a stratigraphic view point, the Paleoproterozoic lands of the Man's Ridge is composed of two lithological assemblages [16] [24], that are also outcropping near our study area (Figure 3): the lower Bririmian (B1), tholeiitic (2166 \pm 66 $\mathrm{Ma}$ ) [25], consisting mainly of detrital sediments and carbonate rocks, and the upper Birimian (B2), more heterogeneous, composed of sedimentary rocks (volcanoclastites, turbidites, shales and carbonates) and calc-alkaline magmatic rocks dated between 2100 and $2150 \mathrm{Ma}$ [26]. It should be noted that the upper Birimian is in some places covered with Tarkwaian fluvio-deltaic sediments [10].

\section{Material and Methods}

We followed two methodological steps:

1) field work:

- geological mapping of the Alahina sector with selection of sample collection sites (artisanal gold mining sites, former mechanized gold mining quarries);

- structural measurements and sampling. Samples collected: meta-sediment and hydrothermal quartz vein;

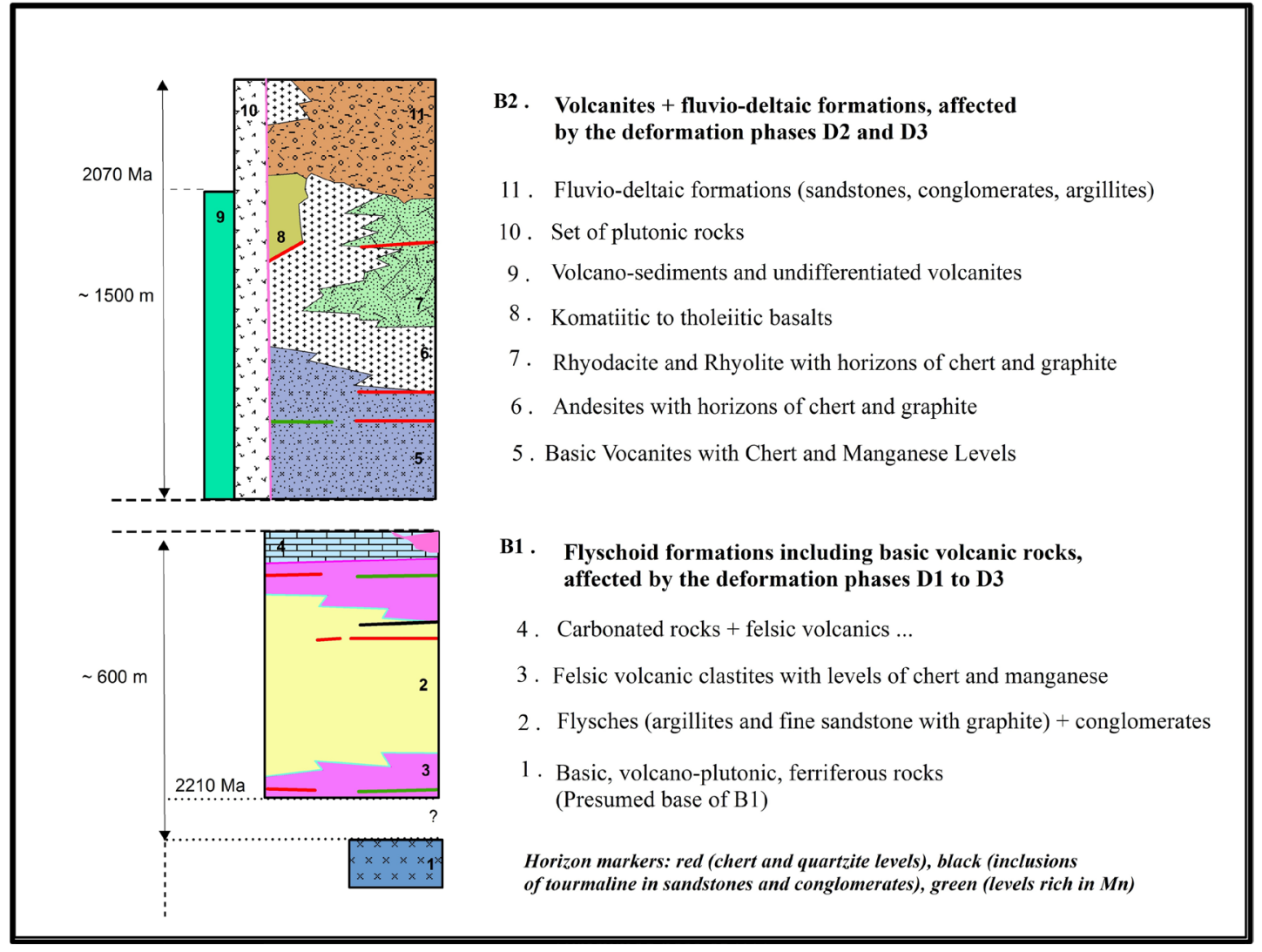

Figure 3. Simplified stratiqgrphic collar of paleoproterozoic lands in the siguiri volcano-sedimentary basin ([16], modified). 
- megascopic analysis of the samples (with the naked eye and with a magnifying glass).

2) laboratory work

- making thin sections and polished sections;

- petrographic study of the samples under a microscope;

- geochemical analysis of the samples;

- treatment, analysis and interpretation of the results.

Sixteen (16) rock samples including twelve (12) meta-sediments and four (04) hydrothermal quartz veins were collected over the study area. Thin sections and polished sections are made and the petrographic determinations were made in Moscow (University of the People's Friendship, Russia) and Abomey-Calavi (Laboratory of Geology, Mines and Environment, University of Abomey-Calavi, Benin). The petrographic study is made macroscopically and thanks to the metallographic microscope equipped with an image capture device connected to a computer. Total rock geochemical analyses are carried out at the SGS MINERAL Ltd. mineral analysis laboratory in Randfontein, South Africa (SANAS accredited laboratory and ISO/IEC 17025 certified), X-ray fluorescence (XRF) for major elements and the Inductively Coupled Plasma Mass Spectrometer (ICP MS) for trace elements, except gold, platinum and palladium, which are analyzed by optical emission spectrometry (ICP OES), after a fusion lead and digestion with aqua regia.

Our samples are treated according to the same analytical protocol. A representative sample of about ten centimeters in diameter is selected. Half of this sample is archived, the other half is divided into two quarters. The first quarter was used for the chemical analysis of major and trace elements by X-ray fluorescence and ICP-MS/OES on powders, the second quarter is used for the manufacture of polished sections and thin sections.

The metallographic microscope used, type Olympus BX60, is equipped with 4 magnification objectives, $\times 5, \times 20, \times 50, \times 100$. It is possible to add objectives. This microscope makes observations in natural light and in polarized light from lighting positioned above the sample, through the lens. The main characteristics of minerals determined in natural light are mineral color, pleochroism, mineral form, zonation, reflectivity, hardness and cleavage. In polarized light, the determining characteristics were polarization color, intensity of anisotropy, twins, scattered light, and corrosion to light.

The analysis of the major elements is made from powders with a particle size less than $40 \mu \mathrm{m}$, obtained after grinding and sieving in an agate mortar in order to avoid any contamination. These powders are then subjected to a lithium borate $\left(\mathrm{LiBO}_{2}\right)$ fusion and then to aqua regia digestion prior to $\mathrm{X}$-ray fluorescence spectrometry. The solution obtained, subjected to highly energetic X-ray radiation, reacts by emitting radiation characteristic of the elements that make up the sample. These emitted radiations are separated on a diffraction analyzer crystal according to the Bragg law ( $2 d \sin \theta=n \lambda$ ), then counted by means of a scintilla- 
tion or gas flow detector. We used a wavelength dispersive spectrometer operating with a rhodium anticathode X-ray tube equipped with a $28 \mathrm{~mm}$ sample holder with a diameter of $28 \mathrm{~mm}$. The samples were analyzed in rotation to overcome any defects in the homogeneity of the analysis surface and under vacuum to limit the absorption of low energy radiation by the air. The instrument is equipped with 3 collimators, 5 crystal analyzers and two detectors specific to a field of energy. Characteristic line calibration of the elements was performed by correlating the certified reference concentrations with the measured and corrected intensities of the matrix effects. The relative accuracy is less than $2 \%$ for the overall analysis of a sample.

The analysis of the trace elements (except gold, platinum and palladium) was performed by ICP-MS spectrometry on solutions obtained after a sodium peroxide $\left(\mathrm{Na}_{2} \mathrm{O}_{2}\right)$ fusion and a regia water digestion of sample powders. ICP-MS spectrometry is a fast multi-elemental analysis technique that allows the Argon to ionize the constituent elements of the analyzed solution. Depending on their mass, the electrons accelerated by a quadrupole shock one after the other, the detector. It is then sufficient to count the number of shots corresponding to a given time. This number of moves corresponds to the quantity of the element. To do this, we used internal standards, Indium and Rhenium, previously incorporated in each sample, a machine blank, the international geostandard, and a $2 \% \mathrm{HNO}_{3}$ solution that passes under the argon flux every half -hours to decrease the memory effect on each sample. A standard Barium solution is also applied to the rate of bi-charged ions.

Optical emission spectrometry consisted of applying electrical energy in the form of an arc or spark (under argon) between the sample and an electrode to vaporize the atoms. These atoms or ions excited in the plasma create an emission spectrum specific to each element of the sample.

The major and trace element concentrations of our samples were treated with different diagrams to determine the nature, provenance and geotectonic environment of meta-sediments and hydrothermal quartz veins they contain. These are the diagrams $\mathrm{TiO}_{2}$ versus $\mathrm{SiO}_{2}$ [27], $\mathrm{Log}\left(\mathrm{Na}_{2} \mathrm{O} / \mathrm{K}_{2} \mathrm{O}\right)$ versus $\mathrm{Log}\left(\mathrm{SiO}_{2} / \mathrm{Al}_{2} \mathrm{O}_{3}\right)$ [28], A-CN-K and CIA [29], Eu/Eu* versus $(\mathrm{Gd} / \mathrm{Yb})_{\mathrm{N}}$ [30] modified by [31], $\mathrm{K}_{2} \mathrm{O} / \mathrm{Na}_{2} \mathrm{O}$ versus $\mathrm{SiO}_{2}[32]$, and DF1 versus DF2 [33].

\section{Results}

\subsection{Petrographic Characteristics of Metasediments}

From a macroscopic view point, the Alahina metasediments have a schistose facies, ranging from greenish-gray to yellowish-gray or brown (Figure 4(a)), sometimes blackish with more remarkable schistosity (Figure 4(b)). The schistosity is marked by an alternation of greenish-gray beds, sometimes dark, 8 - 10 $\mathrm{cm}$ thick, affected by mineral stretch lineations, with thin dark-brown beds (1 - 3 $\mathrm{mm}$ thick). The greenish-gray bands consist mainly of quartz, feldspars, sericite and chlorite while the dark beds are mainly composed of quartz, feldspars, limo- 
nite, hematite and sericite.

Multiple fractures and intense hydrothermal alteration affected the meta-sediments. The corridors created by these fractures are materialized by quartz veins, of thickness varying between $2 \mathrm{~mm}$ and $30 \mathrm{~cm}$. Hydrothermal alteration is characterized by carbonation (ankerite and calcite), chloritization, seritization, and pyritization of the hanging wall of the veins (Figure 4(a)). Gold is often not visible to the naked eye because it is extremely thin and associated with sulphides. In the areas of intense weathering, there is a discoloration of the rocks that changes from a greenish color due to the abundance of chlorite to a beige or gray color due on the one hand, to carbonates, and secondly the leaching of pervasive chlorite (Figure 4(a)).

From a microscopic point of view, the analyzed meta-sediment samples generally have a lepidoblastic texture with the following mineralogical association:

- quartz: not very abundant (20\%) with remarkable rolling extinction. It is an aggregate of almost isometric crystals, dispersed and stretched parallel to the direction of the major schistosity, about $0.005 \mathrm{~mm}$ in size (Figure 5(a));

- sericite: abundant (50\%), in small flakes, evenly distributed. Its size varies between 0.005 and $0.01 \mathrm{~mm}$ (Figure 5(a));

- chlorite: less abundant than sericite (20\%), in subautomorphous and evenly distributed small lamellae varying in size from 0.005 to $0.01 \mathrm{~mm}$ with a mean positive relief in polarized light;

- epidote: less common (6\%), crystallized in the form of small interlocking grains (0.01-0.005 $\mathrm{mm}$ ), very strong relief and oblique extinction $30^{\circ}$;

- magnetite: fairly rare (3\%), opaque, isometric or slightly elongated, with a size of about 0.01 to $0.02 \mathrm{~mm}$ (Figure $5(\mathrm{a})$ );

- apatite: accessory mineral (1\%), hexagonal, gray with a strong relief in polarized light, it is in the form of crystals of small dimensions, of the order of 0.005 to $0.0025 \mathrm{~mm}$.

In the vicinity of the hydrothermal quartz veins, the meta-sediments have particular textures: porphyroblastic (Figures 5(b)-(d)), granoblastic, lepidogranoblastic (Figure 5(e)). The porphyroblastic texture appears with a remarkable proportion of rectangular or square phenocrysts (15\%) (Figure 5(b)). Porpyroblasts are tremo
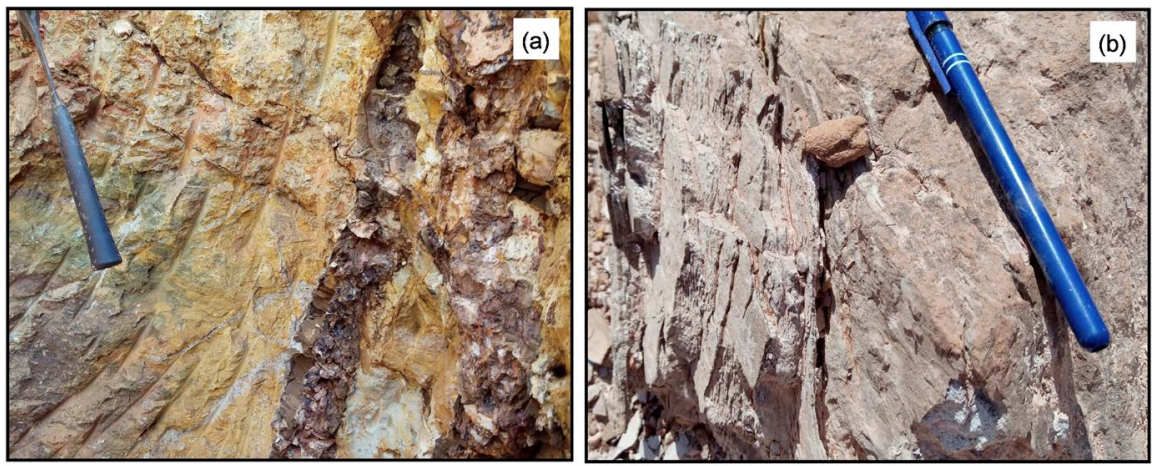

Figure 4. Photographs of the metasediments studied: (a) altered schist with two deformed hydrothermal quartz veins. (b) black schist, irregularly foliation. 

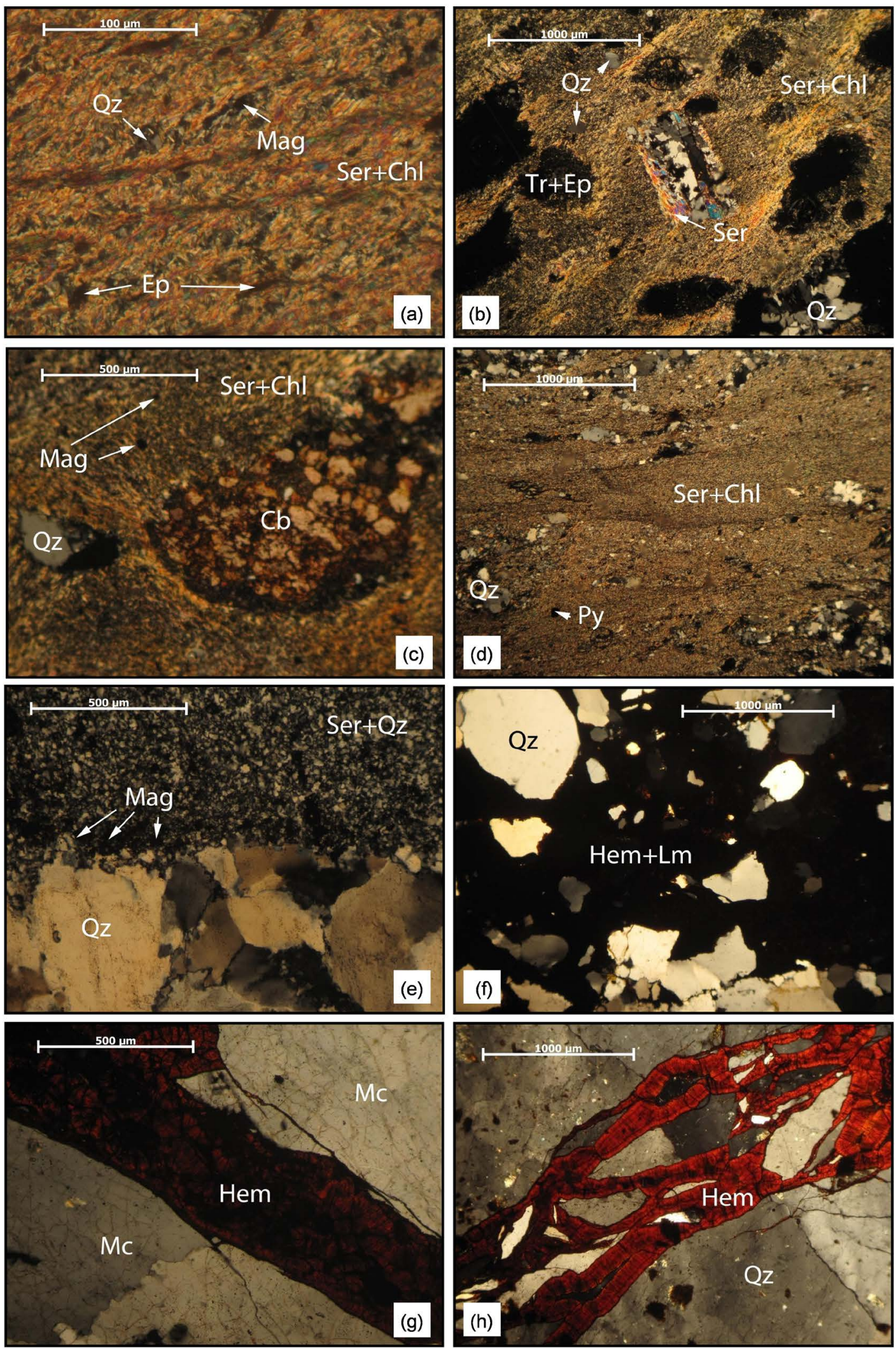

[Act—actinote, $\mathrm{Ap}$-apatite, $\mathrm{Cb}$-carbonate, $\mathrm{Chl}$-chlorite, $\mathrm{Ep}$-epidote, $\mathrm{Hem}$-hématite, Leu-Leucoxene, Lm—limonite (oxides and hydroxides iron), Mag-magnetite, Mc—microcline, Py—pyrite, Ser—sericite, Tr-tremolite, Qz-quartz].

Figure 5. Photomicrographs of meta-sediments (a)-(e) and hydrothermal quartz veins (f)-(h) studied. 
lite and actinolite lenses, $11^{\circ}-17^{\circ}$ oblique extinction, with fine crystals $(0.005$ $\mathrm{mm}$ ) of neoformed quartz. The size of the phenocrysts varies from 0.5 to $1 \mathrm{~mm}$. Coarse, almost round isometric and round grains $(0.15 \mathrm{~mm})$ with wavy extinction and a gray tint are also observed (Figure 5(b) and Figure 5(c)). The epidote is observed on the photomicrograph (Figure $5(\mathrm{~b})$ ) in the vicinity of a hydrothermal quartz vein. The same is true for opaque minerals (4\%, Figure 5(c)). These opaque minerals are in almost isometric clusters, ranging in size from 0.005 to $0.0025 \mathrm{~mm}$ (Figure 5(c)). Rounded or rectangular cavities, filled with carbonates, are also observed on the framework formed by quartz, sericite and chlorite (Figure $5(\mathrm{c})$ ), with a combination of sulphide minerals (1\%), especially cubic pyrite $(0.75 \mathrm{~mm}$ of side (Figure $5(\mathrm{~d}))$. The granoblastic texture, the pidogranoblastic, locally serrated (suture) (Figure 5(e)) emanates from the development of microscopically coarse quartz veins $(0.5 \mathrm{~mm})$ and wavy extinction, on the finer grain sericite frame of quartz $(0.005 \mathrm{~mm})$. The quartz veins thickness is about $2 \mathrm{~mm}$. The lepidogranoblastic texture band does not exceed 0.3 $\mathrm{mm}$. It contains neoformed metallic crystals, magnetite, and probably hematite and leucoxene (Figure 5(e)).

The hydrothermal quartz veins contained in the meta-sediments, generally of a multi-centimeter thickness, have a porphyritic texture. They consist of oxides, hematite and iron hydroxides (limonite), deposited within the quartz fragments (Figure 5(f)). These quartz fragments are uniaxial positive and show a gray hue, sometimes with a dull yellowish hue in polarized light. They are characterized by wavy extinction and their size often exceeds $0.5 \mathrm{~mm}$ (Figure 5(f)). Some hydrothermal quartz veins display a cataclastic, porphyritic, sometimes collomorphic texture (Figure 5(g) and Figure 5(h)). The fragments are angular, disaggregated (breched) and consist of quartz and potassium feldspars. These fragments ranging in size from $2 \mathrm{~mm}$ to $1 \mathrm{~cm}$ are clogged with collomorphic hematite deposits (Figure 5(g) and Figure 5(h)).

\subsection{Nature and Provenance of Metasediments}

The study of major and trace elements provides information about rocks and minerals formation conditions. Authors [17] [34] [35] [36] have studied rocks similar to those of this study and none of them reveal anomalies likely to modify the geochemical characters. Thus, we use the major and trace elements to highlight the petro-geochemical characteristics of the Alahina meta-sediments. Table 1 and Table 2 below mention respectively the composition in major and trace elements of the studied meta-sediments. Table 2 also presents PAAS compositions: Post-Archean Average Australian Shale and EP GRAY: Average Chemical Composition of Early Proterozoic Grauwackes.

For the major elements, the meta-sediment samples studied have a $\mathrm{SiO}_{2}$ composition range of between $48.7 \%$ and $71.25 \%$ and $\mathrm{Al}_{2} \mathrm{O}_{3}$ between $13 \%$ and $28.30 \%$. The other major elements are in the following proportions: $\mathrm{Fe}_{2} \mathrm{O}_{3}(3.05 \%$ - 61\%), $\mathrm{CaO}$ (0.20\% - 2.97\%); $\mathrm{MgO}\left(1.24 \%\right.$ - 4.71\%); $\mathrm{Na}_{2} \mathrm{O}$ (1.37\% - 6.06\%); $\mathrm{K}_{2} \mathrm{O}$ 
Table 1. Major element composition (in \%) of metasediments in the Alahina sector.

\begin{tabular}{|c|c|c|c|c|c|c|c|c|c|c|c|c|}
\hline Echantillon & $\mathrm{T} 22$ & REP-T22 & $\mathrm{T} 23$ & $\mathrm{~T} 24$ & $\mathrm{~T} 25$ & KG1 & KG2 & KG3 & KG4 & KG5 & KG6 & KG7 \\
\hline $\mathrm{SiO}_{2}$ & 69.80 & 69.80 & 67.70 & 48.70 & 69.80 & 71.25 & 65.10 & 64.03 & 61.36 & 64.20 & 65.15 & 62.01 \\
\hline $\mathrm{Al}_{2} \mathrm{O}_{3}$ & 14.40 & 14.60 & 16.00 & 28.30 & 14.40 & 13.00 & 17.90 & 15.01 & 18.70 & 17.30 & 17.11 & 18.32 \\
\hline $\mathrm{Fe}_{2} \mathrm{O}_{3}$ & 6.10 & 6.11 & 4.19 & 6.13 & 6.26 & 3.05 & 3.55 & 4.63 & 3.60 & 3.98 & 3.15 & 3.98 \\
\hline $\mathrm{CaO}$ & 0.20 & 0.21 & 0.22 & 0.03 & 0.22 & 2.97 & 1.18 & 1.43 & 1.64 & 2.12 & 1.65 & 1.07 \\
\hline $\mathrm{MgO}$ & 1.84 & 1.84 & 1.24 & 1.25 & 1.91 & 3.76 & 3.04 & 4.71 & 3.48 & 3.41 & 2.94 & 2.89 \\
\hline $\mathrm{Na}_{2} \mathrm{O}$ & 4.01 & 4.06 & 3.09 & 1.37 & 4.13 & 2.66 & 4.52 & 6.06 & 5.78 & 4.72 & 4.52 & 3.72 \\
\hline $\mathrm{K}_{2} \mathrm{O}$ & 1.09 & 1.09 & 3.43 & 6.81 & 1.06 & 2.17 & 2.48 & 1.10 & 2.80 & 2.45 & 2.44 & 4.07 \\
\hline $\mathrm{Cr}_{2} \mathrm{O}_{3}$ & 0.01 & 0.01 & 0.03 & 0.03 & 0.00 & 0.01 & 0.00 & 0.02 & 0.01 & 0.02 & 0.02 & 0.00 \\
\hline $\mathrm{TiO}_{2}$ & 0.65 & 0.65 & 0.62 & 1.14 & 0.65 & 0.34 & 0.57 & 0.61 & 0.46 & 0.51 & 0.44 & 0.63 \\
\hline $\mathrm{MnO}$ & 0.03 & 0.03 & 0.01 & 0.00 & 0.03 & 0.08 & 0.06 & 0.06 & 0.06 & 0.08 & 0.07 & 0.05 \\
\hline $\mathrm{P}_{2} \mathrm{O}_{5}$ & 0.11 & 0.11 & 0.14 & 0.03 & 0.12 & 0.16 & 0.14 & 0.23 & 0.12 & 0.16 & 0.12 & 0.14 \\
\hline $\mathrm{V}_{2} \mathrm{O}_{5}$ & 0.02 & 0.02 & 0.02 & 0.09 & 0.02 & 0.02 & 0.02 & 0.04 & 0.02 & 0.03 & 0.04 & 0.50 \\
\hline LOI & 2.55 & 2.60 & 3.43 & 6.36 & 2.73 & 2.00 & 2.01 & 2.03 & 3.01 & 2.05 & 2.04 & 3.01 \\
\hline Total & 100.81 & 101.13 & 100.12 & 100.24 & 101.33 & 101.47 & 100.57 & 99.96 & 101.04 & 101.03 & 99.69 & 100.39 \\
\hline $\mathrm{CaO}+\mathrm{Na}_{2} \mathrm{O}$ & 4.21 & 4.27 & 3.31 & 1.40 & 4.35 & 5.63 & 5.70 & 7.49 & 7.42 & 6.84 & 6.17 & 4.79 \\
\hline $\log \left(\mathrm{Fe}_{2} \mathrm{O}_{3} / \mathrm{K}_{2} \mathrm{O}\right)$ & 0.75 & 0.75 & 0.09 & -0.05 & 0.77 & 0.15 & 0.16 & 0.62 & 0.11 & 0.21 & 0.11 & -0.01 \\
\hline $\log \left(\mathrm{SiO}_{2} / \mathrm{Al}_{2} \mathrm{O}_{3}\right)$ & 0.69 & 0.68 & 0.63 & 0.24 & 0.69 & 0.74 & 0.56 & 0.63 & 0.52 & 0.57 & 0.58 & 0.53 \\
\hline CIA & 73.10 & 73.15 & 70.36 & 77.51 & 72.69 & 62.50 & 68.63 & 63.60 & 64.66 & 65.06 & 66.52 & 67.40 \\
\hline $\mathrm{FeO}$ & 5.49 & 5.50 & 3.77 & 5.52 & 5.63 & 2.74 & 3.19 & 4.17 & 3.24 & 3.58 & 2.83 & 3.58 \\
\hline DF1 & -4.69 & -4.86 & -5.42 & -13.25 & -4.86 & -1.14 & -1.78 & 2.27 & -1.93 & -2.37 & -1.40 & -4.28 \\
\hline DF2 & 6.29 & 6.30 & 5.85 & 2.30 & 6.45 & 6.92 & 7.21 & 9.13 & 8.05 & 7.66 & 7.26 & 6.35 \\
\hline $\mathrm{K}_{2} \mathrm{O} / \mathrm{Na}_{2} \mathrm{O}$ & 0.27 & 0.27 & 1.11 & 4.97 & 0.26 & 0.82 & 0.55 & 0.18 & 0.48 & 0.52 & 0.54 & 1.09 \\
\hline
\end{tabular}

Table 2. Trace element composition (in ppm) of Alahina metasediments.

\begin{tabular}{cccccccccccccc}
\hline Echantillons & T22 & T23 & T24 & T25 & KG1 & KG2 & KG3 & KG4 & KG5 & KG6 & KG7 & PAAS & EP GREY \\
\hline $\mathrm{Au}$ & $<0.02$ & 0.14 & 0.48 & 0.02 & 0.02 & $<0.02$ & 0.25 & $<0.02$ & 0.45 & $<0.02$ & 0.15 & - & - \\
$\mathrm{Pt}$ & $<0.02$ & $<0.02$ & $<0.02$ & $<0.02$ & $<0.02$ & $<0.02$ & $<0.02$ & $<0.02$ & $<0.02$ & $<0.02$ & $<0.02$ & - & - \\
$\mathrm{Pd}$ & $<0.02$ & $<0.02$ & 0.04 & $<0.02$ & 0.02 & $<0.02$ & $<0.02$ & $<0.02$ & 0.03 & $<0.02$ & $<0.02$ & - & - \\
$\mathrm{Ba}$ & 244 & 376 & 1450 & 233 & 452 & 278 & 352 & 375 & 401 & 297 & 398 & - & - \\
$\mathrm{Be}$ & 3.2 & 0.8 & 1 & 6.2 & 3 & 5.1 & 5.1 & 0.6 & 5.3 & 6 & 6.1 & - & - \\
$\mathrm{Co}$ & 13.7 & 5.7 & 1.8 & 12.1 & 5.3 & 14 & 11.7 & 6.4 & 12.3 & 15 & 6.2 & - & - \\
$\mathrm{Cs}$ & 2.1 & 3.7 & 7.9 & 1.8 & 4.7 & 7.8 & 1.9 & 5 & 5.1 & 7.8 & 2.9 & - & - \\
$\mathrm{Ga}$ & 15 & 18 & 35 & 15 & 28 & 19 & 22 & 38 & 17 & 28 & 19 & - & - \\
$\mathrm{Sr}$ & 221 & 120 & 107 & 229 & 205.3 & 241.3 & 118.8 & 217.6 & 118 & 199.9 & 177.4 & - \\
$\mathrm{As}$ & 16 & 788 & 250 & 50 & 698 & 48 & 177 & 102 & 508 & 210 & 499 & - \\
$\mathrm{Ag}$ & 2 & 2 & 2 & 4 & 2 & 2 & 3 & 2 & 2 & 4 & 3 & - \\
\hline
\end{tabular}




\begin{tabular}{|c|c|c|c|c|c|c|c|c|c|c|c|c|c|}
\hline $\mathrm{Zn}$ & 64 & 23 & 30 & 58 & 13.5 & 28.8 & 91.3 & 29.6 & 35.1 & 32.5 & 36.8 & - & - \\
\hline $\mathrm{Cu}$ & 13 & 30 & 16 & 14 & 13.6 & 12.7 & 35.7 & 4.5 & 11.7 & 10.8 & 18.6 & - & - \\
\hline $\mathrm{Pb}$ & 20 & 12 & 17 & 15 & 8.8 & 12.6 & 23.1 & 4.6 & 7.8 & 3.3 & 5.4 & - & - \\
\hline In & $<0.2$ & $<0.2$ & $<0.2$ & $<0.2$ & $<0.2$ & $<0.2$ & $<0.2$ & $<0.2$ & $<0.2$ & $<0.2$ & $<0.2$ & - & - \\
\hline $\mathrm{Ge}$ & 2 & 2 & 3 & 1 & 2 & 2 & 1 & 2 & 3 & 1 & 3 & - & - \\
\hline $\mathrm{Nb}$ & 9 & 9 & 15 & 8 & 8 & 11 & 16 & 8 & 13 & 9 & 13 & - & - \\
\hline $\mathrm{Rb}$ & 46.1 & 106 & 267 & 44.4 & 89.6 & 147.3 & 57.8 & 66.8 & 99.2 & 78 & $114 ; 9$ & - & - \\
\hline Sn & 6 & 5 & 6 & 4 & 3 & 5 & 7 & 5 & 4 & 3 & 4 & - & - \\
\hline Mo & $<2$ & $<2$ & 4 & $<2$ & $<2$ & $<2$ & 5 & $<2$ & $<2$ & $<2$ & $<2$ & - & - \\
\hline $\mathrm{Sr}$ & 221 & 120 & 107 & 229 & 220 & 144 & 102 & 171 & 229 & 99 & 117 & - & - \\
\hline Th & 6.4 & 5.9 & 9.3 & 6.8 & 7.2 & 9.6 & 8.1 & 4.9 & 7.2 & 11 & 6.2 & 14.6 & 8 \\
\hline $\mathrm{U}$ & 2.21 & 2.04 & 4.37 & 2.38 & 6.41 & 1.9 & 1.88 & 3.8 & 3.55 & 4.9 & 8.1 & - & - \\
\hline $\mathrm{V}$ & 103 & 97 & 454 & 103 & 124 & 77 & 97.5 & 103.2 & 98 & 184 & 106 & - & - \\
\hline $\mathrm{W}$ & 4 & 18 & 15 & 4 & 7 & 4 & 11 & 8 & 9 & 12 & 8 & - & - \\
\hline $\mathrm{Sb}$ & 1.3 & 1.6 & 1.3 & 0.8 & 1.6 & 0.8 & 0.8 & 0.9 & 1.2 & 0.8 & 1.2 & - & - \\
\hline $\mathrm{Zr}$ & ND & ND & ND & ND & ND & ND & ND & ND & ND & ND & ND & 210 & 156 \\
\hline $\mathrm{Tl}$ & 0.9 & 0.8 & 1.6 & 0.5 & 0.7 & 0.8 & 1.2 & 1.1 & 0.6 & 0.6 & 0.9 & - & - \\
\hline $\mathrm{Ni}$ & 21 & 10 & $<5$ & 14 & 7.9 & 24.4 & 24.7 & 13.9 & 17.1 & 16.1 & 23.5 & - & - \\
\hline $\mathrm{La}$ & 41.2 & 32.4 & 40.2 & 37.2 & 24.9 & 27.8 & 49.7 & 45.7 & 38.8 & 43.7 & 40.8 & 38.2 & 32 \\
\hline $\mathrm{Ce}$ & 85.4 & 58.4 & 71.8 & 88.5 & 69 & 73 & 83 & 85.4 & 79 & 83.2 & 72 & 79.6 & 68 \\
\hline $\operatorname{Pr}$ & 10.4 & 7.38 & 10.1 & 10.5 & 8 & 6.49 & 11 & 7.6 & 9.3 & 10.6 & 7.9 & 8.83 & - \\
\hline $\mathrm{Nd}$ & 34.9 & 27.8 & 32.5 & 34.2 & 28 & 28.3 & 31 & 25.1 & 31.1 & 24.5 & 35.2 & 33.9 & 29 \\
\hline $\mathrm{Sm}$ & 6.5 & 5.3 & 7.8 & 6.4 & 6.1 & 4.9 & 6.2 & 4.47 & 4.36 & 6 & 3.8 & 5.55 & 5.6 \\
\hline $\mathrm{Eu}$ & 1.62 & 1.16 & 1.84 & 1.31 & 1.3 & 1.27 & 1.71 & 1.45 & 1.39 & 1.23 & 1.57 & 1.08 & 1.2 \\
\hline $\mathrm{Gd}$ & 4.34 & 3.8 & 5.22 & 4.02 & 4.1 & 4.6 & 5.1 & 5.1 & 5.1 & 4.4 & 4.8 & 4.66 & 4.54 \\
\hline $\mathrm{Tb}$ & 0.83 & 0.73 & 1.13 & 0.69 & 0.8 & 0.81 & 0.85 & 0.78 & 0.91 & 0.8 & 0.9 & 0.77 & 0.66 \\
\hline Dy & 3.78 & 3.51 & 7.07 & 3.88 & 4 & 4.81 & 6.2 & 5.2 & 6.3 & 5.3 & 5.78 & 4.68 & - \\
\hline Ho & 0.74 & 0.64 & 1.38 & 0.82 & 0.71 & 1.2 & 1.28 & 0.67 & 0.8 & 0.99 & 1.2 & 0.99 & - \\
\hline Er & 1.85 & 1.4 & 3.35 & 1.44 & 1.74 & 1.8 & 2.7 & 1.95 & 2.4 & 1.6 & 3.3 & 2.85 & - \\
\hline $\mathrm{Tm}$ & 0.31 & 0.29 & 0.69 & 0.35 & 0.3 & 0.59 & 0.57 & 0.6 & 0.48 & 0.29 & 0.41 & 0.405 & - \\
\hline $\mathrm{Yb}$ & 2.1 & 1.7 & 4.3 & 2.3 & 2.2 & 2.27 & 3.9 & 2.5 & 2 & 2.8 & 2.15 & 2.82 & 1.8 \\
\hline $\mathrm{Lu}$ & 0.44 & 0.35 & 0.79 & 0.39 & 0.3 & 0.6 & 0.8 & 0.62 & 0.5 & 0.5 & 0.41 & 0.43 & 0.29 \\
\hline $\mathrm{Eu} / \mathrm{Eu}^{*}$ & 0.88 & 0.75 & 0.83 & 0.74 & 0.75 & 0.81 & 0.90 & 0.93 & 0.90 & 0.70 & 1.13 & 0.63 & 0.71 \\
\hline $\mathrm{Ce} / \mathrm{Ce}^{*}$ & 0.98 & 0.88 & 0.84 & 1.07 & 1.18 & 1.27 & 0.83 & 1.01 & 0.98 & 0.91 & 0.91 & 1.01 & 1.64 \\
\hline $\mathrm{La} / \mathrm{Yb}$ & 13.24 & 12.87 & 6.31 & 10.92 & 7.64 & 8.27 & 10.49 & 12.34 & 13.10 & 10.54 & 12.81 & 9.15 & 12.00 \\
\hline $\mathrm{La} / \mathrm{Sm}$ & 3.96 & 3.82 & 3.22 & 3.63 & 2.55 & 3.54 & 5.01 & 6.38 & 5.56 & 4.55 & 6.70 & 4.30 & 3.57 \\
\hline $\mathrm{Gd} / \mathrm{Yb}$ & 1.66 & 1.80 & 0.98 & 1.41 & 1.50 & 1.63 & 1.28 & 1.64 & 2.05 & 1.26 & 1.80 & 1.33 & 2.03 \\
\hline
\end{tabular}


$(1.09 \%-6.81 \%) ; \mathrm{TiO}_{2}(0.35 \%-1.14 \%) ; \mathrm{P}_{2} \mathrm{O}_{5}(0.03 \%-0.33 \%)$ and $\mathrm{V}_{2} \mathrm{O}_{5}(0.02 \%-$ $0.5 \%)$. These rocks have been subjected to a metamorphism causing a redistribution of some elements such as $\mathrm{K}_{2} \mathrm{O}$ and $\mathrm{Na}_{2} \mathrm{O}$ while others are immobile $\left(\mathrm{SiO}_{2}\right.$ and $\left.\mathrm{TiO}_{2}\right)$. These immobile chemical elements $\left(\mathrm{SiO}_{2}\right.$ and $\left.\mathrm{TiO}_{2}\right)$ can provide information on the nature of the protholite of our samples as well as their provenance.

Thus, in the $\mathrm{TiO}_{2}$ versus $\mathrm{SiO}_{2}$ classification scheme [27], all the meta-sediments analyzed are rich in $\mathrm{SiO}_{2}$ with varying concentrations of $\mathrm{TiO}_{2}$ and are positioned in the field of sedimentary rocks (Figure 6(a)). Identical results are obtained using classification scheme based on $\log \left(\mathrm{Fe}_{2} \mathrm{O}_{3} / \mathrm{K}_{2} \mathrm{O}\right)$ versus $\left.\mathrm{Log} \mathrm{SiO}_{2} / \mathrm{Al}_{2} \mathrm{O}_{3}\right)$ [28]. The meta-sediments analyzed showed low $\mathrm{SiO}_{2} / \mathrm{Al}_{2} \mathrm{O}_{3}$ and $\mathrm{Fe}_{2} \mathrm{O}_{3} / \mathrm{K}_{2} \mathrm{O}$ ratios and would come from shales (sometimes rich in iron) and grauwakes (Figure 6(b)).

The alteration degree of meta-sediment precursor is evaluated from the chemical alteration index (CIA) [37]: $\mathrm{CIA}=100 *\left[\mathrm{Al}_{2} \mathrm{O}_{3} /\left(\mathrm{Al}_{2} \mathrm{O}_{3}+\mathrm{CaO}^{*}+\mathrm{Na}_{2} \mathrm{O}+\mathrm{K}_{2} \mathrm{O}\right)\right]$
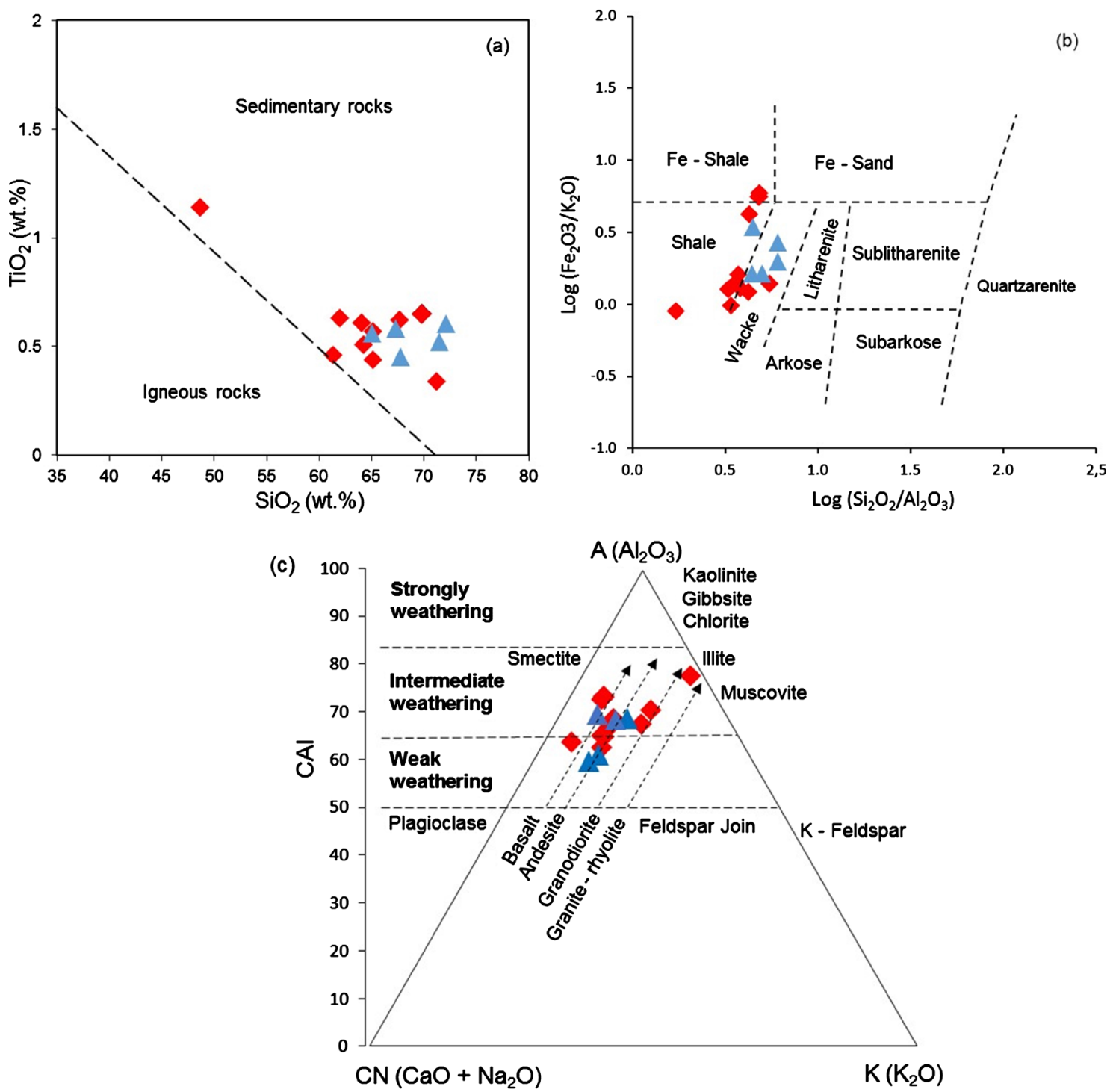

Figure 6. Metasediments location in diagrams: (a) $\mathrm{TiO}_{2}$ versus $\mathrm{SiO}_{2}$ [27]; (b) $\mathrm{Log}\left(\mathrm{Na}_{2} \mathrm{O} / \mathrm{K}_{2} \mathrm{O}\right)$ versus $\log \left(\mathrm{SiO}_{2} / \mathrm{Al}_{2} \mathrm{O}_{3}\right)$ [28]; (c) A-CN-K and CIA [29]. [Triangles in blue represent metasediment data from the work of [38]]. 
$(\mathrm{CaO} *$ corresponds to the concentration of $\mathrm{CaO}$ incorporated in the silicate fraction of the rock). For example, rocks with CIA $>92$ values are strongly altered due to the transformation of feldspars into clay minerals [39]. Rocks with CIA values between 60 and 80 with atmospheric alteration and CIA $<60$ show no or little alteration [29]. The meta-sediments analyzed have CIA values between 62.5 and 77.51 and indicate an atmospheric alteration of the protholite of these rocks.

The intensity of the alteration as well as the nature of the original sediments was indicated by the ternary diagram A-CN-K and CIA [29] (Figure 6(c)). Thus, our samples plotted in this diagram (Figure 6(c)) are positioned in the field of an intermediate alteration and prove that sediments in the Alahina sector derive from andesite, basalt and granodiorite. It should be noted that some of the meta-sediments analyzed are smectite rich and others in illite and muscovite, indicating the diversity of sources of provenance.

Rare earth elements (REE) patterns of Alahina meta-sediments (Figure 7) were compared to PAA: Post-Archean Average Australian Shale [40], as well as to EP GRAY: Early Proterozoic Chemical Composition. Greywackes [41]. These samples show a moderate LREE/HREE fractionation of $(\mathrm{La} / \mathrm{Yb})_{\mathrm{N}}=6.31-13.24$, a flat pattern for heavy rare earth elements (HREE), $(\mathrm{Gd} / \mathrm{Yb})_{\mathrm{N}}=0.98-2.05$ and negative anomalies in europium at low amplitude. The characteristics of these meta-sediments are similar to those of PAAS and EP GRAY, providing additional evidence concerning the pelitic and semi-pelitic composition of Alahina metasediments. In addition, the values of $\mathrm{Eu} / \mathrm{Eu}^{*}$ and $\mathrm{Gd}_{\mathrm{N}} / \mathrm{Yb}_{\mathrm{N}}$ ratios are in the range of values $\left(\mathrm{Eu} / \mathrm{Eu}^{*}>0.7 ; \mathrm{Gd}_{\mathrm{N}} / \mathrm{Yb}_{\mathrm{N}}>1.0\right)$ found in Archean meta-sediments by [30] and [31] (Figure 8 ).

\subsection{Geotectonic Environment of Metasediments}

The geodynamic deposition environment of the detrital sediments that led to the formation of the metasediments object of the present study is appreciated from the

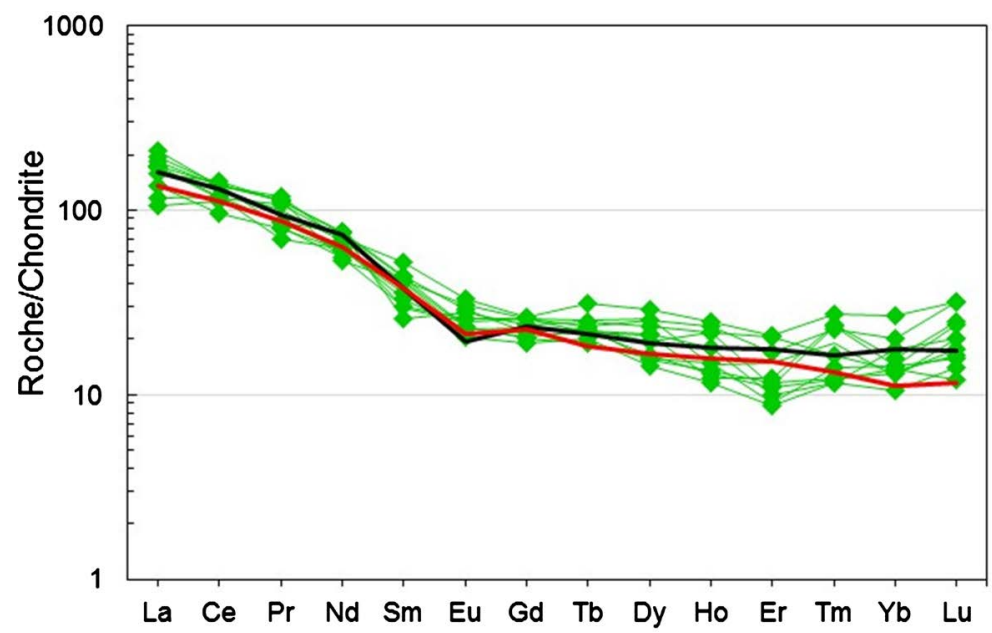

Figure 7. Chondrite-normalized rare earth element patterns [42] applied to Alahina Meta-sediments, PAAS, and GRAY EPs. [Green line with rhombus represents the Alahina meta-sediments. Black line represents PAAS and red line, the EP GRAY]. 
discriminating diagrams of [32] and [33]. Thus, in the Roser and Korsch diagram, the analyzed meta-sediments are positioned in two domains: the oceanic island arcs margins domain and the active continental margins domain (Figure 9(a)). However, the discriminant diagram from Bhatia shows a membership of metasediments in oceanic island arcs domain (Figure 9(b)).

\subsection{Mineralizations Associated with Alahina Metasediments}

The petrographic study showed mineralization within the meta-sediments already affected by tectonic deformations.

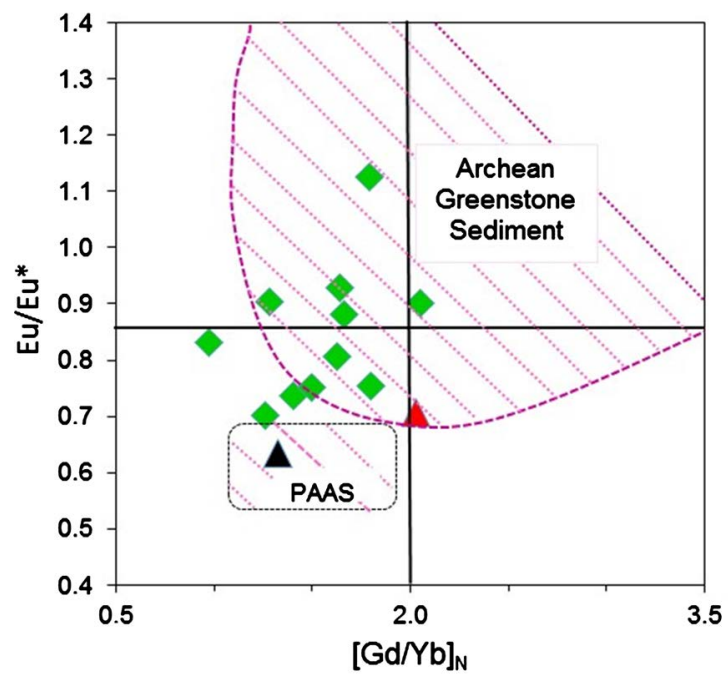

Figure 8. Metasediments location in the $\mathrm{Eu} / \mathrm{Eu}^{*}$ versus $(\mathrm{Gd} / \mathrm{Yb})_{\mathrm{N}}$ diagram from [30], modified by [31]. [Green rhomb represents the meta-sediments, the black triangle the PAAS and the red the EP GRAY].
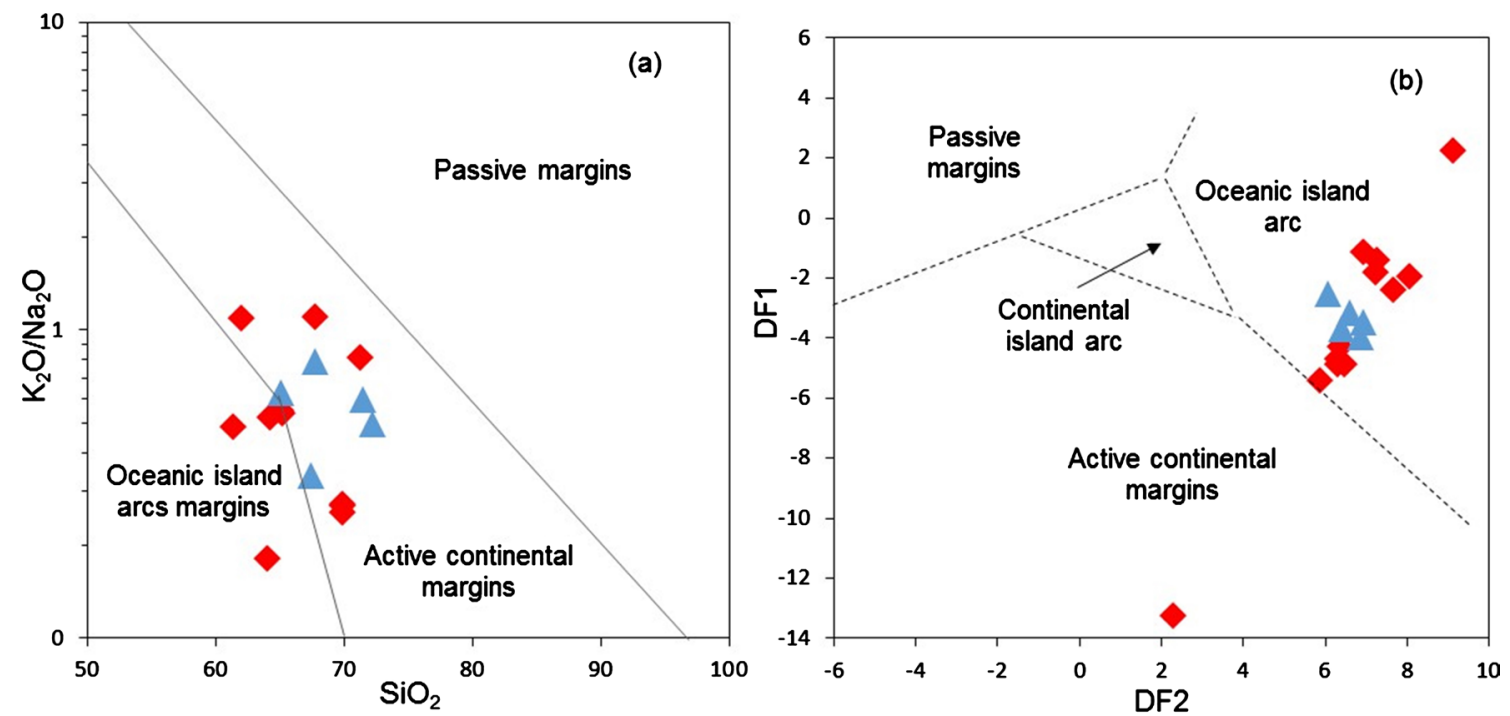

[Triangles in blue represent metasediment data from Adama et al. (2014). DF1 $=-0.421 \mathrm{SiO}_{2}+1.988 \mathrm{TiO}_{2}-0.526 \mathrm{Al}_{2} \mathrm{O}_{3}-$ $0.551 \mathrm{Fe}_{2} \mathrm{O}_{3}-1.610 \mathrm{FeO}+2.720 \mathrm{MnO}+0.881 \mathrm{MgO}-0.907 \mathrm{CaO}-0.177 \mathrm{Na}_{2} \mathrm{O}-1.840 \mathrm{~K}_{2} \mathrm{O}+7.244 \mathrm{P}_{2} \mathrm{O}_{5}+43.57 . \mathrm{DF} 2=-0.0447 \mathrm{SiO}_{2}$ $-0.972 \mathrm{TiO}_{2}+0.008 \mathrm{Al}_{2} \mathrm{O}_{3}-0.267 \mathrm{Fe}_{2} \mathrm{O}_{3}+0.208 \mathrm{FeO}-3.082 \mathrm{MnO}+0.140 \mathrm{MgO}+0.195 \mathrm{CaO}+0.719 \mathrm{Na}_{2} \mathrm{O}-0.032 \mathrm{~K}_{2} \mathrm{O}+7.510 \mathrm{P}_{2} \mathrm{O}_{5}$ $+0.303]$.

Figure 9. Metasediments location in diagrams: (a) $\mathrm{K}_{2} \mathrm{O} / \mathrm{Na}_{2} \mathrm{O}$ versus $\mathrm{SiO}_{2}$ from [32], (b) DF1 versus DF2 from [33]. 


\section{- Veins and mineralization}

Fluid associated with metamorphic and tectono-sedimentary event affecting meta-sediments in the Alahina sector has spread as veins of three types $V_{1}, V_{2}$ and $\mathrm{V}_{3}$.

Veins $V_{1}$, of a millimeter thickness, are placed in the schistosity planes $S_{0}-S_{1}$ (Figure 10(a)). They are affected by a ductile-brittle strain D1 (Figure 10(a) \&
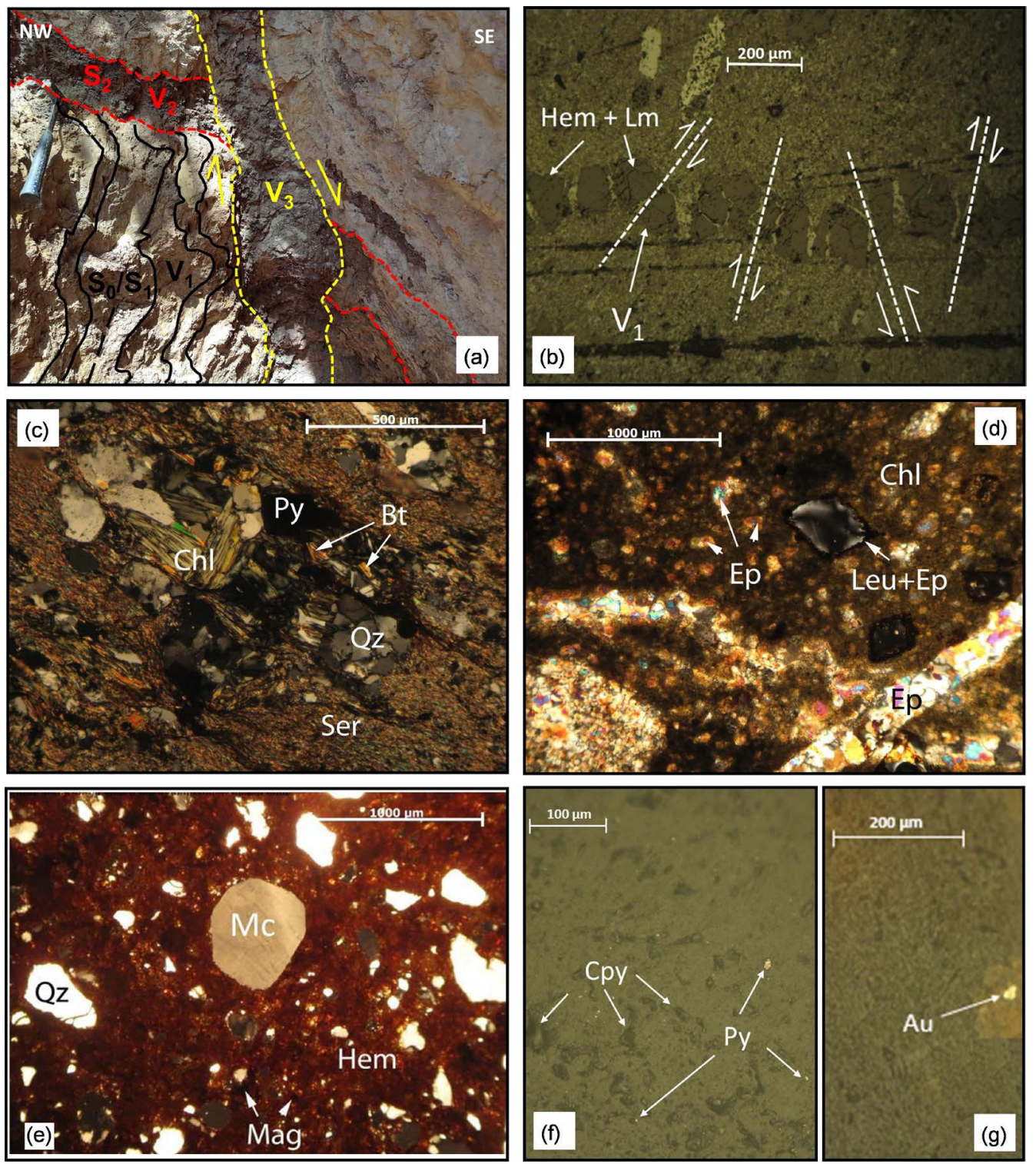

[Act-actinote, Ap-apatite, Apy-arsenopyrite, Au-or, Bt—biotite, Chl-chlorite, Cpy-chalcopyrite, Ep-epidote, Hem-hematite, Leu-Leucoxene, Lm-limonite, Mag-magnetite, Mc-microcline, Py-pyrite, Ser-sericite, $\mathrm{Tr}$-tremolite, Qz-quartz].

Figure 10. Macroscopic and microscopic appearance of Alahina metasediments showing hydrothermal quartz veins and diffuse mineralization: (a) photomicrograph of a shale intersected by three types of $\mathrm{V}_{1}, \mathrm{~V}_{2}$ and $\mathrm{V}_{3}$ veins affected by folds in an area of NE directional dextral shear; (b) photomicrograph of a chloritized shale traversed by a vein of hematite $\left(V_{1}\right)$ pleated and fractured; $(c)-(d)$ microphotography of different zones of diffuse mineralization; (e)-(g) photomicrograph of different zones of veins showing oxidized, sulphidized minerals or gold. 
Figure 10(b)) generating open folds whose axes have a direction varying between $\mathrm{N} 80^{\circ}$ and $\mathrm{N} 100^{\circ}$ (measured in situ). Veins $\mathrm{V}_{2}$ are parallel to $\mathrm{S}_{2}$ schistosity or NE shear zones and intersect veins $\mathrm{V}_{1}$ (Figure 10(a)). They are arranged "in step" and affected by ductile-brittle D2 deformation characterized by driving folds and fractures of direction NE. Their thickness often varies from $2 \mathrm{~cm}$ to 30 $\mathrm{cm}$. Veins $\mathrm{V}_{3}$ intersect $\mathrm{V}_{2}$ veins associated with $\mathrm{S}_{2}$ schistosity following NE dextral shear (Figure 10(a)).

These different veins are generally recrystallized in silica, carbonates, micas, sulphides, oxides and precious metals thanks to the circulation of hydrothermal fluids responsible for neoformations.

\section{- Phases of mineralization and their location}

Three hydrothermal phases have been distinguished: 1) a phase with silico-sericite-chloritized and sulphurized parageneses, often diffuse or stratiform, consisting of $\mathrm{Qz}_{\mathrm{I}}-\mathrm{Ser}-\mathrm{Chl} \pm \mathrm{Ep} \pm \mathrm{Tr} \pm \mathrm{Act} \pm \mathrm{Cb} \pm \mathrm{Ap}-\mathrm{Py}_{\mathrm{I}} \pm \mathrm{Apy}_{\mathrm{I}} \pm \mathrm{Mg}_{\mathrm{I}} \pm \mathrm{Leu}_{\mathrm{I}} \pm$ $\mathrm{Hem}_{\mathrm{I}}$ for veins $\mathrm{V}_{1}$ which is localized in meta-sediments (Figure 10(b) \& Figure 10(c)); 2) two phases with sulphurised, locally serititized and/or chloritized sulphide feldspathic parageneses, consisting of $\mathrm{Qz}_{\mathrm{II}}-\mathrm{Cb}_{\mathrm{II}}-\mathrm{Mc}_{\mathrm{II}} \pm \mathrm{Ser} \pm \mathrm{Chl} \pm \mathrm{Ep}_{\mathrm{III}}-\mathrm{Py}_{\mathrm{II}}$ $\pm \mathrm{Mg}_{\mathrm{II}} \pm \mathrm{Leu}_{\mathrm{II}} \pm \mathrm{Hem}_{\mathrm{II}}-\mathrm{Cpy}_{\mathrm{II}}-\mathrm{Au}_{\mathrm{II}}$ et $\mathrm{Qz}_{\mathrm{III}}-\mathrm{Cb}_{\mathrm{III}}-\mathrm{Mc}_{\mathrm{III}} \pm \mathrm{Ser} \pm \mathrm{Chl} \pm \mathrm{Ep}_{\mathrm{III}}-\mathrm{Py}_{\mathrm{III}} \pm$ $\mathrm{Mg}_{\mathrm{III}} \pm \mathrm{Leu}_{\mathrm{III}} \pm \mathrm{Hem}_{\mathrm{III}}-\mathrm{Cp}_{\mathrm{III}}-\mathrm{Au}_{\mathrm{III}}$, forming respectively the stock of veins $\mathrm{V}_{2}$ and $\mathrm{V}_{3}$ (Figures 10(d)-(f)).

\section{Discussion}

\subsection{Petrographic Features, Origin and Geotectonic Environment of Metasediments}

The metasediments studied are sericite and chlorite schists traversed by quartz veins containing auriferous sulphides and oxides. The minerals that characterize these schists are: quartz, potassic feldspars (rather rare), sericite, chlorite, epidote, apatite, actinolite, tremolite, carbonate, biotite, sulphides, magnetite, hematite and ilmenite. The presence of certain metamorphic minerals such as chlorite, epidote and actinol testifies the sedimentary origin of our samples and prove that they were subjected to low grade metamorphism (Temperature $=$ $250^{\circ} \mathrm{C}-500^{\circ} \mathrm{C}$, Pressure $=2-10$ kilobars, depth $=5-30 \mathrm{~km}$ ), with shale facies [36] [43] [44]. These shales consist of shales and greywackes, set up in an oceanic island arc and active continental margin environment, as well as the metasediments located in Yanfolila belt, in western Mali [38], in Agbahou Fettêkro furrow in Ivory Coast [45] and the paragneisses of Granja in northeastern Brazil [44]. The basaltic, andesitic and granodioritic source of our samples is consistent with the juvenile character of the Birimian formations.

This study has shown the archaic character that the Birimian schist could have. The rare earth elements pattern of the meta-sediments are similar to the Early Gray Protein Gray Chemicals of [39], and have in addition values of the $\mathrm{Eu} / \mathrm{Eu}^{*}$ and $\mathrm{Gd}_{\mathrm{N}} / \mathrm{Yb}_{\mathrm{N}}$ ratios in the range of values $\left(\mathrm{Eu} / \mathrm{Eu}^{*}>0.7 ;[\mathrm{Gd} / \mathrm{Yb}]_{\mathrm{N}}>1.0\right)$ found in Archean meta-sediments by [30] and [31]. The existence of Archean 
relics (3200 Ma) in the paragneissic area of Tabou and Grand-Bereby in southwestern Côte d'Ivoire [17] [35] [36] is in agreement with this result. It is therefore obvious that Alahina's green shale originates from the disintegration of $\mathrm{Pa}$ leoarchean migmatitic gneisses and metagabbros ( 3500 Ma [9]. These Archean metamorphic rocks are adjacent to the Siguiri volcano-sedimentary basin and outcrop in southeastern Guinean territory at the base of the Nimba Mountains [2] [3] Meta-sediments with iron-rich shales as protoliths are probably Archean.

Although present in meta-sediments, trace elements such as $\mathrm{Au}, \mathrm{Pt}, \mathrm{Pd}, \mathrm{Ba}$, Be, Co, Cs, Ga, Sr, As, Ag, Zn, Cu, Pb, In, Ge, Nb, Rb, Sn, Mo, Sr, Th, U, V, W, $\mathrm{Sb}, \mathrm{Zr}, \mathrm{Tl}$ and $\mathrm{Ni}$ have not been specifically analyzed. However, their presence should be indicated because of the mineralogical associations that accompany gold areas, including arsenic, zinc, lead, copper, and silver in gold sulphides.

\subsection{Genetic Model of Mineralization Associated with Alahina Metasediments}

The Alahina metasediments are affected by deformations and traversed by hydrothermal fluids with deposition of silica and sulphide [46] and/or oxidized minerals such as pyrite, chalcopyrite, gold, magnetite, hematite, ilmenite and to a lesser extent, arsenopyrite. Gold mineralization occurs in a context of polyphase (ductile-brittle and brittle) tectonic deformation marked by NE shear. The work from [3] on the Siguiri gold mine in Guinea (eastern zone of this study area) indicates four tectonic deformation phases: NS compression (D1S), EW compression (D2S) progressively evolving into a transpression then in a transtension (D3S) and finally compression NW-SE (D4S). [47] and [48] reported that the Ashanti gold deposits (Ashanti, Konongo, Bogosu, Prestea and Abawso mines) are found in NE-SW shear-zones at NNE-SSW and intersecting Birimian sediments near the contact with the volcanites. Like these deposits, gold mineralization in Alahina sector is associated with shear zone-type deformations. The genetic mineralization model commonly accepted in such a geological context is that of a continuum of fluid flows from ductile stages to brittle stages in relation to the triggering of earthquakes, according to the "fault-valve" model proposed by [49]. Indeed, each time the fluids pressure exceeds the lithostatic pressure, it causes rocks fracturing in localized zones which will thus constitute drains facilitating hydrothermal fluids circulation, creating the mineralized zones [50]. With the decrease of pressure, these fluids precipitate their mineral charge which will be found thus in filling of veins. Two types of mineralization can be mentioned in the Alahina sector: disseminated and veined. The existence of disseminated mineralization that would be syngeneic is based on the presence of nanoparticles of pyrite, magnetite, hematite, ilmenite within the metasediments independently of the veins or veins.

\section{Conclusions}

Alahina metasediments in the northeastern Guinea area consist of sericite and 
chlorite schists. Geochemical data suggest that schists are composed of shales and greywackes and derive from andesites, basalts and granodiorites erosion. These rocks would be emplaced in a tectonic environment of active continental margin and/or oceanic island arcs. These shales and greywackes may also have resulted from the erosion of migmatitic gneisses and Archean metagabbros at the base of the mountain range bordering the Siguiri Basin. The rare earth element patterns of the metasediments show a rare REE enrichment $\left(\mathrm{La}_{\mathrm{N}} / \mathrm{Yb}_{\mathrm{N}}=\right.$ 6.31 - 13.24) and a flat HREE pattern. This pattern is almost identical to those of the "Post-Archean average Australian Shale" and the lower Proterozoic Grauwackes. The Alahina shale is for some Archean metasediments, thus indicating the possible incorporation of Archean crust in the magmas of the gneisses protoliths located at the base of Nimba Mountains, at the edge of Siguiri volcano-sedimentary basin and dated about $3500 \mathrm{Ma}$.

Two types of gold mineralization occur in the Alahina area: disseminated and veined. They consist of particular of grains and nanoparticles pyrite associated with gold, magnetite, hematite, ilmenite. The hydrothermal alteration accompanying this gold mineralization consists of silica, microcline, chlorite-epidote-sericitecarbonates.

\section{Conflicts of Interest}

The authors declare no conflicts of interest regarding the publication of this paper.

\section{References}

[1] Lebrun, E., Miller, J., Thébaud, N., Ulrich, S. and McCuaig, T.C. (2016) Structural Controls on an Orogenic Gold System: The World-Class Siguiri Gold District, Siguiri Basin, Guinea, West Africa. Economic Geology, 112, 73-98. https://doi.org/10.2113/econgeo.112.1.73

[2] Mamedov, V.I., Boufeev, Y.V. and Nikitine, Y.A. (2010) Géologie de la Republique de Guinée. Volume I. Geosprospects Ltd. Universite d'Etat de moscou Lomonossov M. (Faculté géologique), $320 \mathrm{p}$.

[3] Lebrun, O.E. (2016) 4D of the Orogenic Gold District of Siguiri (West Africa). Doctor of Philosophy Thesis, Université du Québec à Monréal, Québec, 221 p.

[4] Parra, L.A., Fiorentini, M.L., Miller, J., McCuaig, C., Bourassa, Y. and Perrouty, S. (2013) Age Constraints on Host Rocks for Gold Mineralisation in the Ashanti Belt, Ghana. Extended Abstract, 12th SGA Biennial Meeting, Uppsala, 12-15 August 2013, 4 p.

[5] Tshibubudze, A., Hein, K.A.A., Peters, L.F.H., Woolfe, A.J. and McCuaig, T.C. (2013) Oldet U-Pb Crystallisation Age for the West African Craton from the Oudalan-Gorouol Belt of Burkina-Faso. South African Journal of Geology, 116, 169-181. https://doi.org/10.2113/gssajg.116.1.169

[6] Davis, D.W., Hirdes, W., Schaltegger, U. and Nunoo, E.A. (1994) U-Pb Age Constraints on Deposition and Provenance of Birimian and Gold-Bearing Tarkwaian Sediments in Ghana, West Africa. Precambrian Research, 67, 89-107. https://doi.org/10.1016/0301-9268(94)90006-X

[7] Le Mignot, E., Siebenaller, L., Béziat, D., André-Mayer, A.-S., Reisberg, L., Salvi, S., 
Velasquez, G., Zimmermann, C. and Naré, A. (2017) The Paleoproterozoic Copper Gold Deposits of the Gaoua District, Burkina Faso: Superposition of Orogenic Gold on a Porphyry Copper Occurrence? Economic Geology, 112, 99-122. https://doi.org/10.2113/econgeo.112.1.99

[8] De Kock, G.S., Armstrong, R.A., Siegfried, H.P. and Thomas, E. (2011) Geochronology of the Birim Supergroup of the West African Craton in the Wa-Bolé Region of West-Central Ghana: Implications for the Stratigraphic Framework. Journal of African Earth Sciences, 59, 1-40. https://doi.org/10.1016/j.jafrearsci.2010.08.001

[9] Thiéblemont, D., Delor, C., Cocherie, A., Lafon, J.M., Goujou, J.C., Baldé, A., Bah, M., Sané, H. and Mark Fanning, C. (2001) A 3.5 Ga Granite-Gneiss Basement in Guinea: Further Evidence for Early Archean Accretion within the West African Craton. Precambrian Research, 108, 179-194. https://doi.org/10.1016/S0301-9268(00)00160-1

[10] Hirdes, W. and Davis, D.W. (2002) U-Pb Geochronology of Paleoproterozoic Rocks in the Southern Part of the Kedougou-Kéniéba Inlier, Senegal, West Africa: Evidence for Diachronous Accretionary Development of the Eburnean Province. Precambrian Research, 118, 83-99. https://doi.org/10.1016/S0301-9268(02)00080-3

[11] Lahondère, D., Thiéblemont, D., Tegyey, M., Guerrot, C. and Diabaté, B. (2002) First Evidence of Early Birimian (2.21 Ga) Volcanic Activity in Upper Guinea: The Volcanics and Associated Rocks of the Niani Suite. Journal of African Earth Sciences, 35, 417-431. https://doi.org/10.1016/S0899-5362(02)00145-8

[12] Egal, E., Thiéblemont, D., Lahondère, D., Guerrot, C., Costea, C.A., Iliescu, D., Delor, C., Goujou, J.C., Lafon, J.M., Tegyey, M., Diaby, S. and Kolié, P. (2002) Late Eburnean Granitization and Tectonics along the Western and Northwestern Margin of the Archean Kénéman-Man Domain (Guinea, West African Craton). Precambrian Research, 117, 57-84. https://doi.org/10.1016/S0301-9268(02)00060-8

[13] Milési, J.P., Ledru, P., Marcoux, E., Mougeot, R., Johan, V., Lerouge, C., Sabaté, P., Bailly, L., Respaut, J.P. and Skipwith, P. (2002) The Jacobina Paleoproterozoic Gold-Bearing Conglomerates, Bahia, Brazil: A "Hydrothermal Shear-Reservoir" Model. Ore Geology Reviews, 19, 95-136. https://doi.org/10.1016/S0169-1368(01)00038-5

[14] Abouchami, W., Boher, M., Michard, A. and Albarède, F. (1990) A Major 2.1 Ga Event of Mafic Magmatism in West Africa: An Early Stage of Crustal Accretion. Journal of Geophysical Research, 95, 17605-17629. https://doi.org/10.1029/JB095iB11p17605

[15] Miller, J.M., Davis, J., Baratoux, L., McCuaig, T.C., Metelka, V. and Jessel, M. (2013) Evolution of Gold Systems in Guinea, Southern Mali and Western Burkina Faso. AMIRA International Ltd. P934A-West African Exploration Initiative-Stage 2 Final Unpublished Report, Appendix D1, 127-234.

[16] Milési, J.-P., Feybesse, J.-L., Ledru, P., Dommanget, A., Ouedraogo, M.-F., Marcoux, E., Prost, A., Vinchon, C., Sylvain, J.P. and Johan, V. (1989) West African Gold Deposits in Their Lower Proterozoic Lithostructural Setting. Chroniques de La Recherche Minière France, 497, 3-98.

[17] Kouamelan, A.N., Peucat, J.-J. and Delor, C. (1997) Reliques archéennes (3.15 Ga) au sein du magmatisme birimien $(2.1 \mathrm{Ga})$ de Côte d'lvoire, craton ouest-africain. Comptes rendus de 1 Académie des Sciences, 324, 719-727.

[18] Begg, G.C., Grittin, W.L., Natapov, L.M., O’Relly, S.Y., Grand, S.P., O’Nelli, C.J., Hronsky, J.M.A., Djomani, Y.P., Swain, C.J., Deen, T. and Bowden, P. (2009) The Lithospheric Architecture of Africa: Seismic Tomography, Mantle Petrology and Tectonic Evolution. Geosphere, 5, 23-50. https://doi.org/10.1130/GES00179.1 
[19] Lawrence, D.M., Treloar, P.J., Rankin, A.H., Harbidge, P. and Holliday, J. (2013) The Geology and Mineralogy of the Loulo Mining District, Mali, West Africa: Evidence for Two Distinct Styles of Orogenic Gold Mineralization. Economic Geology, 108, 199-227. https://doi.org/10.2113/econgeo.108.2.199

[20] McFarlane, C.R.M., Mavrogenes, J., Lentz, D., King, K., Allibone, A. and Holcombe, R. (2011) Geology and Intrusion-Related Affinity of the Morila Gold Mine, Southeast Mali. Economic Geology, 106, 727-750. https://doi.org/10.2113/econgeo.106.5.727

[21] BRGM (1999) Notice explicative de la carte géologique à $1 / 200,000$, feuille $n^{\circ} 12$ siguiri, $1^{\text {ère }}$ édition.

[22] Treloar, P., Lawrence, D., Senghor, D., Boyce, A. and Harbidge, P. (2015) The Massawa Gold Deposit, Estern Senegal, West Africa: An Orogenic Gold Deposit Sourced from Magmatically Derived Fluid? Geological Society, London, Special Publication, Vol. 393, 135-160. https://doi.org/10.1144/SP393.12

[23] Hanssen, E., Kalsin, J. and Tessouhue, S. (2004) The Yatela Gold Mine, Western Mali: Supergene Enrichissement of Lower Proterozoic Gold Mineralization in a Structural Karst. Abstract in Proceeding of: CIM Annual Meeting, Edmonton, Canada, 2004.

[24] Vidal, M., Delor, C., Pouclet, A., Siméon, Y. and Alric, G. (1996) Evolution géodynamique de l'Afrique de l'Ouest entre 2,2 Ga et $2 \mathrm{Ga}$; le style "archéen" des ceintures vertes et des ensembles sédimentaires birimiens du nord-est de la Côte d'Ivoire. Bulletin de La Société Géologique de France, 167, 307-319.

[25] Leube, A., Hirdes, W., Mauer, R. and Kesse, G.O. (1990) The Early Proterozoic Birimian Supergroup of Ghana and Some Aspects of Its Associated Gold Mineralization. Precambrian Research, 46, 139-165. https://doi.org/10.1016/0301-9268(90)90070-7

[26] Feybesse, J.L., Billa, M., Guerrot, C., Duguey, E., Lescuyer, J.L., Milési, J.P. and Bouchot, V. (2006) The Paleoproterozoic Ghanaian Province: Geodynamic Model and Ore Controls, Including Regional Stress Modeling. Precambrian Research, 149, 149-196. https://doi.org/10.1016/j.precamres.2006.06.003

[27] Tarney J. (1977) Petrology, Mineralogy and Geochemistry of the Falkland Plateau Basement Rocks, Site 300, Deep Sea Drilling Proect. Initial Report, 36, 893-921. https://doi.org/10.2973/dsdp.proc.36.123.1977

[28] Herron, M.M. (1988) Geochemical Classification of Terrigenous Sands and Shales from Core or Log Data. Journal of Sedimentary Petrology, 58, 820-829. https://doi.org/10.1306/212F8E77-2B24-11D7-8648000102C1865D

[29] Fedo, C.M., Nesbitt, H.W. and Young, G.M. (1995) Unraveling the Effects of Potassium Metasomatism in the Sedimentary Rocks and Paleosols with Implications for Paleoweathering Conditions and Provenance. Geology, 23, 921-924. https://doi.org/10.1130/0091-7613(1995)023<0921:UTEOPM>2.3.CO;2

[30] McLennan, S.M. and Taylor, S.R. (1991) Sedimentary Rocks and Crustal Evolution: Tectonic Setting and Secular Trends. The Journal of Geology, 99, 1-21. https://doi.org/10.1086/629470

[31] McLennan, S.M., Hemming, S.R., Taylor, S.R. and Eriksson, K.A. (1995) Early Proterozoic Crustal Evolution: Geochemical and $\mathrm{Nd}-\mathrm{Pb}$ Isotopic Evidence from Metasedimentary Rocks, Southwestern North America. Geochimica et Cosmochimica Acta, 59, 1153-1177. https://doi.org/10.1016/0016-7037(95)00032-U

[32] Roser, B.P. and Korsch, R.J. (1986) Discrimination of Tectonic Setting of Sandstone-Mudstone Suites Using $\mathrm{SiO}_{2}$ Content and $\mathrm{K}_{2} \mathrm{O} / \mathrm{Na}_{2} \mathrm{O}$ Ratio. Journal of Geolo- 
gy, 94, 635-650. https://doi.org/10.1086/629071

[33] Bhatia, M. (1983) Plate Tectonics and Geochemical Composition of Sandstones. The Journal of Geology, 91, 611-627. https://doi.org/10.1086/628815

[34] Papon, A. (1973) Géologie et minéralisations du Sud-Ouest de la Côte d'Ivoire. Mémoire du BRGM, 80, $284 \mathrm{p}$.

[35] Kouamelan, A.N., Djro, S.C., Allialy, M.E., Paquette, J.L. and Peucat, J.J. (2015) The Oldest Rock of Ivory Coast. Journal of African Earth Sciences, 103, 65-70. https://doi.org/10.1016/j.jafrearsci.2014.12.004

[36] Kouadio, F.J.L.H., Chérubin, D.S., Nicaise, K.A., Ephrem, A.M. and Augustin, K.Y. (2016) Petrographical and Geochemical Signatures of Paragneisses of Tabou and Grand-Béréby Sectors (South-West of Ivory Coast). International Journal of Innovation and Applied Studies, 18, 646.

[37] Nesbitt, H. and Young, G. (1984) Prediction of Some Weathering Trends of Plutonic and Volcanic Rocks Based on Thermodynamic and Kinetic Consideration. Geochimica Cosmochimica Acta, 48, 1523-1534. https://doi.org/10.1016/0016-7037(84)90408-3

[38] Adama, S., Youssef, D., Stefano, S., Olivier, F., Luc, S., Mohammed, B., Didier, B., Mohamed, D., Ahmed, N., Samira, A. and Pierre, D. (2014) Géologie des minéralisations aurifères du gisement tardi-éburnéen de Kalana (Birimien, Sud-Ouest du Mali). Bulletin de PInstitut Scientifique, Rabat, Section Sciences de la Terre, 36, 85-108.

[39] Potter, P.E., Maynard, J.B. and Depetris, P. (2005) Mud and Mudstones Introduction and Overview. Springer Science and Business Media, New York, 296. https://doi.org/10.1007/b138571

[40] Nance, W.B. and Taylor, S.R. (1976) Rare-Earth Element Patterns and Crustal Evolution, Australian Post-Archean Sedimentary-Rocks. Geochimica et Cosmochimica Acta, 40, 1539-1551. https://doi.org/10.1016/0016-7037(76)90093-4

[41] Condie, K.C. (1993) Chemical Composition and Evolution of the Upper Continental Crust: Contrasting Results from Surface Samples and Shales. Chemical Geology, 104, 1-37. https://doi.org/10.1016/0009-2541(93)90140-E

[42] Sun, S.S. and McDonough, W.F. (1989) Chemical and Isotopic Systematics of Oceanic Basalts: Implications for Mantle Composition and Processes. Geological Society, London, Special Publications, 42, 313-345. https://doi.org/10.1144/GSL.SP.1989.042.01.19

[43] Block, S., Ganne, J., Baratoux, L., Zeh, L., Parra-Avila, A., Jessell, M., Aillères, L. and Siebenaller, L. (2015) Petrological and Geochronological Constraints on Lower Crust Exhumation during Paleoproterozoic (Eburnean) Orogeny, NW Ghana, West African Craton. Journal of Metamorphic Geology, 33, 463-494.

[44] Silva, A.J.F., Azevedo, M.R., Aguad Valle, B., Nogueira Neto, J.A., Santos, T.J.S. and Silva, F.D.O. (2014) Petrographical and Geochemical Signatures of the Granja Paragneisses (Médio Coreaú Domain, NW Ceará, Brasil). Estudios Geológicos Juliodiciembre, 70, e014. https://doi.org/10.3989/egeol.41750.326

[45] Houssou, N.N. (2013) Etude pétrologique, structurale et métallogénique du gisement aurifère d'Agbahou, Divo, Côte d'Ivoire. Thèse de Doctorat, Université Félix Houphouët-Boigny, $176 \mathrm{p}$.

[46] Comana Mining (2019) Rapport de synthèse des travaux d'exploration de l'or sur le permis 2 d'Alahina, période du $1^{\text {er }}$ janvier 2017 au 30 septembre 2019. 12 p.

[47] Oberthür, T., Weiser, T., Amanor, J.A. and Chryssoulis, S.L. (1997) Mineralogical Sitting and Distribution of Gold in Quartz Veins and Sulfide Ores of the Ashanti 
Mine and Other Deposits in the Ashanti Belt of Ghana: Genetic Implications. Mineralium Deposita, 32, 2-15. https://doi.org/10.1007/s001260050068

[48] Wille, S.E. and Klemd, R. (2004) Fluid Inclusion Studies of the Abwasso Gold Prospect, near the Ashanti Belt, Ghana. Mineralium Deposita, 39, 31-45. https://doi.org/10.1007/s00126-003-0380-1

[49] Sibson, R.H. and Scott, J. (1998) Stress/Fault Controls on the Containment and Release of Overpressured Fluids: Examples from Gold-Quartz Vein Systems in Juneau, Alaska; Victoria, Australia and Otago, New Zealand. Ore Geology Reviews, 13, 293-306. https://doi.org/10.1016/S0169-1368(97)00023-1

[50] Sibson, R.H., Robert, F. and Poulsen, K.H. (1988) High Angle Reverse Faults Fluid Pressure Cycling and Mesothermal Gold-Quartz Deposits. Geology, 16, 551-555. https://doi.org/10.1130/0091-7613(1988)016<0551:HARFFP >2.3.CO;2 